\title{
A new approach to $\alpha-\psi$-contractive mappings and generalized Ulam-Hyers stability, well-posedness and limit shadowing results
}

\section{WUTIPHOL SINTUNAVARAT}

\section{ABSTRACT.}

In this paper, we introduce the new concept of weakly $\alpha$-admissible mapping and give example to show that our concept is different from the concept corresponding existing in the literature. We also establish fixed point theorems by using such concept along with $\alpha-\psi$-contractive condition and give some example which support our main result while previous results in literature are not applicable. Moreover, we study the generalized UlamHyers stability, the well-posedness and the limit shadowing for fixed point problems satisfy our conditions.

Acknowledgements. The author would like to thank the Thailand Research Fund and Thammasat University under Grant No. TRG5780013 for financial support during the preparation of this manuscript.

\section{REFERENCES}

[1] Bota, M. F., Karapınar, E. and Mleşniţe, O., Ulam-Hyers stability results for fixed point problems via $\alpha-\psi$ contractive mapping in (b)-metric space, Abstr. Appl. Anal., Volume 2013 (2013), Article ID 825293, 6 pp.

[2] Bota-Boriceanu, M. F. and Petruşel, A., Ulam-Hyers stability for operatorial equations, Analel Univ. Al. I. Cuza, Iaşi, 57 (2011), 65-74

[3] Brzdek, J., Chudziak, J. and Pales, Z., A fixed point approach to stability of functional equations, Nonlinear Anal., 74 (2011), 6728-6732

[4] Cădariu, L. and Radu, V., The fixed points method for the stability of some functional equations, Carpathian J. Math., 23 (2007), No. 1-2, 63-72

[5] Cădariu, L. and Radu, V., Fixed points and the stability of some classes of functional equations, Carpathian J. Math., 24 (2008), No. 3, 299-309

[6] De Blassi, F. S. and Myjak, J., Sur la porosite des contractions sans point fixe, C. R. Math. Acad. Sci. Paris, 308 (1989), 51-54

[7] Hyers, D. H. , On the stability of the linear functional equation, Proceedings of the National Academy of Sciences of the United States of America, 27 (1941), No. 4, 222-224

[8] Kutbi, M. A. and Sintunavarat, W., Ulam-Hyers stability and well-posedness of fixed point problems for $\alpha-\lambda$ contraction mapping in metric spaces, Abstr. Appl. Anal., Volume 2014 (2014), Article ID 268230, 6 pp.

[9] Lahiri, B. K. and Das, P., Well-posednes and porosity of certain classes of operators, Demonstratio Math., 38 (2005), 170-176

[10] Popa, V., Well posedness of fixed point problem in compact metric spaces, Bul. Univ. Petrol-Gaze Ploies. Ser. Mat. Inf. Fiz., 60 (2008), No 1, 1-4

[11] Rus, I. A., Remarks on Ulam stability of the operatorial equations, Fixed Point Theory, 10 (2009), No. 2, 305-320

[12] Rus, I. A., Ulam stabilities of ordinary differential equations in a Banach space, Carpathian J. Math. 26 (2010), No. $1,103-107$

[13] Rus, I. A., Ulam stability of the operatorial equations, Functional equations in mathematical analysis, 287-305, Springer Optim. Appl., 52, Springer, New York, 2012

Received: 13.08.2014; In revised form: 12.03.2015; Accepted: 15.03.2015

2010 Mathematics Subject Classification. 47H10, 54H25.

Key words and phrases. $\alpha$ - $\psi$-contractive mapping, Weakly $\alpha$-admissible mapping, Generalized Ulam-Hyers stability, Well-posedness, Limit shadowing. 
[14] Rus, I. A., Gronwall lemma approach to the Hyers-Ulam-Rassias stability of an integral equation, Nonlinear analysis and variational problems, 147-152, Springer Optim. Appl., 35, Springer, New York, 2010

[15] Rus, I. A. and Şerban, M. A., Basic problems of the metric fixed point theory and the relevance of a metric fixed point theorem, Carpathian J. Math., 29 (2013), No. 2, 239-258

[16] Samet, B., Vetro, C. and Vetro, P., Fixed-point theorems for $\alpha$ - $\psi$-contractive type mappings, Nonlinear Anal., 75 (2012), 2154-2165

[17] Sintunavarat, W., Generalized Ulam-Hyers stability, well-posedness and limit shadowing of fixed point problems for $\alpha$ - $\beta$-contraction mapping in metric spaces, The Scientific World Journal, Volume 2014 (2014), Article ID 569174, $7 \mathrm{pp}$.

[18] Tişe, F. A. and Tişe, I. C., Ulam-Hyers-Rassias stability for set integral equations, Fixed Point Theory, 13 (2012), No. 2, 659-668

DePARTMENT OF MATHEMATICS AND STATistics

FACULTY OF SCIENCE AND TECHNOLOGY

Thammasat UNIVERSiTY RANGSIT CENTER

PATHUMTHANI 12121, THAILAND.

E-mail address: wutiphol@mathstat.sci.tu.ac.th, poom_teun@hotmail.com 